\title{
37. Reşat Coşkun şiirinin tematik bağlamda tahlili
}

Ahmet KARAKUŞ1

APA: Karakuş, A. (2021). Reşat Coşkun şiirinin tematik bağlamda tahlili. RumeliDE Dil ve Edebiyat Araştrmaları Dergisi, (24), 661-678. DOI: 10.2900o/rumelide.995409.

\section{$\ddot{O} \mathbf{z}$}

Reşat Coşkun’un "Küheylan-“Hüdhüdü Beklerken”, "Berceste-Vuslatı Olmayan Sevda”, "Sevdam Kaldı Bir” ve "Sokak Lambası" adlı yayınlanmış olan dört şiir kitabı bulunmakta ve şair genellikle serbest şiir tarzıyla şiirlerini yazmıştır. Coşkun, şiirlerinin bütün insanlığa hitap ettiğini belirtmiş, birçok dile tercüme edilecek kadar sarih olduğunu ifade etmiştir. Reşat Coşkun'un şiirlerinde bazı temaların ise ön plana çıktığı görülmektedir. Bu temaların ortaya çıkmasında şairin yaşantısı önemli bir etken olmaktadır. Coşkun'un Kadirî müntesibi olmasının da şiirine etkisi yadsınamaz bir olgudur. Ayrıca aşk ve sevgili, hüzün ve karamsarlık, inanç ve bu kavram dahilinde din, tasavvuf, ayet ve hadislerin kullanımı, halk ve halk içinde olmaya değer verdiği için yerellik, bunun yanında tasavvufî meselelerde dahi yanlış bulduğu hususları tenkit etmesinden dolayı sosyal eleştiri şiirine yansımaktadır. Şairin intisabının olması Coşkun'un şiirinde aşkın ilahî olarak da yansımasına sebebiyet vermiş olup, şairin fitrî ve psikolojik yapısı ise hüzün ve karamsarlık olarak şiirine girmiştir. Ayet ve hadisler telmih ya da iktibaslarla şairin şiirini beslemiş, doğduğu ve yaşadığı şehir olan Erzurum ise gerek ağız kullanımıyla gerek şehrin coğrafyasıyla gerek şehirdeki bazı yerlerin özellikle vurgulanmasıyla gerekse de şehirde kullanılan ve o şehre has olan ifadelerin yer almasıyla yerellik şiirine katkıda bulunmuştur. Bu hususlarla beraber şairin yanlış gördüğü hususları tenkit etme yapısı sosyal eleştiri şeklinde bir başka tematik unsur olarak şairin şiirine yansımıştır. Bu çalışmada belirtilen temalar tahlil yapılarak incelenmeye ve açıklanmaya çalışılmıştır.

Anahtar kelimeler: Reşat Coşkun, tema, yaşantı, tahlil, etki

\section{Thematic analysis of the poems by Reşat Coşkun}

\begin{abstract}
Reşat Coşkun has three published poem books named "Küheylan-Hüdhüdü Beklerken”, "BercesteVuslatı Olmayan Sevda", "Sevdam Kaldı Bir" and "Sokak Lambası" and he usually writes in free verse. Coşkun states that his poems address the whole humanity and are explicit enough to be translated into numerous languages. It is evident that some themes gain prominence in his poems. Poet's own life is a significant element for the emergence of these themes. Poet's adherence to Kadiri Tariqah has an undeniable influence on his poems. Moreover; love and beloved, gloom and pessimism, faith and religion within this notion, sufism, the use of verses and hadiths, locality -as he appreciates people and being among people, social criticism -as he criticizes the parts he sees wrong even in issues related to Sufism- are reflected in his poems. His adherence to Tariqah causes the reflection of love in divine form and poet's innate and psychological state is determined as gloom and pessimism in his poems. Verses and hadiths foster his poems through reference and quotation; Erzurum, with the use of local dialect, its geography, reiteration of some places in the city and the use of phrases peculiar to the city, contributes to locality. Social criticism, as a way for the poet to express what he evaluates wrong, is
\end{abstract}

$1 \quad$ Öğr. Gör. Dr., Atatürk Üniversitesi, TÖMER (Erzurum, Türkiye), ahmet.karakus@atauni.edu.tr, ORCID ID: 00oo-00028102-3516 [Araştırma makalesi, Makale kayit tarihi: 17.08.2021-kabul tarihi: 20.09.2021; DOI: 10.29000/rumelide.995409]

RumeliDE Dil ve Edebiyat Araştırmaları Dergisi Osmanağa Mahallesi, Mürver Çiçeği Sokak, No:14/8 Kadıköy - ISTANBUL / TÜRKIYE 34714 e-posta: editor@rumelide.com tel: +90 $5057958124,+902167730616$
Address

RumeliDE Journal of Language and Literature Studies Osmanağa Mahallesi, Mürver Çiçeği Sokak, No:14/8

Kadıköy - ISTANBUL / TURKEY 34714

e-mail: editor@rumelide.com,

phone: +90 5057958124 , +90 2167730616 
also reflected in his poems as another thematic component. In this study, aforementioned themes are attempted to be analyzed and explained.

Keywords: Reşat Coşkun, theme, life, analysis, influence

\section{Giriş}

Reşat Coşkun, Erzurum’a bağlı Yağmurcuk Mahallesinde dünyaya gelmiştir. İlk ve orta öğrenimini bu şehirde tamamlayan Coşkun, Atatürk Üniversitesi Fen-Edebiyat Fakültesi Coğrafya bölümünü 1988 yılında bitirmiştir. Millı̂ Eğitim Bakanlı̆̆ı'na bağlı çeşitli okullarda Coğrafya öğretmeni olarak görev yapan Reşat Coşkun, 25 Ağustos 2021 tarihinde elim bir kaza sonucu vefat etmiştir. Şairin "BercesteVuslatı Olmayan Sevda", "Küheylan-Hüdhüdü Beklerken", "Sevdam Kaldı Bir” ve "Sokak Lambası" adlı yayınlanmış olan dört şiir kitabı bulunmaktadır.

Reşat Coşkun şiirinde bir tekâmül vardır. İlk şiirleri daha çok kişiye hitap etmekte sonrakiler ise seçkin okur beklemektedir. Şair; şiirinin insanlığın geneline hitap ettiğini, mesela bir Fransızcaya rahatça çevrilebileceğini söylemiştir ve yaşanmışlıkların şiirine yansıdığını ifade etmiştir. (R. Coşkun ile kişisel iletişim: 18.07.2021).

Şiirlerin genel bir okunması sonucu toplumun değişimi ve dönüşümünü şairin ele aldığı görülmektedir. Şekil olarak bakıldığı zaman ise heceyle yazdığı şiirinin çok az olduğu fark edilecektir. Şiirlerinin neredeyse hepsi serbest tarzda yazılmıştır. Şair bunun sebebini ölçüye uymak adına seçilen bazı kelimelerin saçma olmasına bağlamıştır. Coşkun, ölçü kaygısı taşımadan kötü eserler yazmak istemediğini ifade etmiştir. Ayrıca serbest tarzda ve seçici ürünler verme yanlısı olduğunu da belirtmiştir Coşkun ile kişisel iletişim: 18.07. 2021).

Reşat Coşkun'un şiirinde dikkat çeken bir başka husus ise şiirlerinin bir altyapısı olduğudur. Coşkun'un şiirine bakıldığı zaman şairin Kur'ân'dan, hadisten, yaşadığı şehirden, mesleğinden, yaşadıklarından esinlendiği görülmektedir. Bunların yanında şair bazı hususlarda ise sosyal eleştiri yaparak tepkisini de açık bir şekilde dile getirmektedir.

$\mathrm{Bu}$ çalışmada ilgili temalar ele alınacak olup, bu temalar Coşkun'un şiirlerinden alınan örnekler ile tahlil edilmeye çalışılacaktır.

\section{Reşat Coşkun şiirine tematik olarak bakmak}

Reşat Coşkun şiirinde bazı temaların belirgin olduğu, kapsamlı bir okuma sonucunda fark edilecektir. Bu şiirde aşk ve sevgili, hüzün ve karamsarlık, inançsal hususlar, yerellik ve sosyal eleştiri tema olarak yer almaktadır. Bu temalar başlıklandırma yapılarak incelenmeye çalışllacaktır.

\subsection{Aşk ve sevgili}

Aşkta aslolan akıl değil, gönüldür. Akılla hareket edilmesi bazı problemleri beraberinde getirecektir. Sevgi olmadığı için çıkar ön plana çıkacaktır. Sevgilinin sevenin aklını bertaraf ettiğì, "Esmeralda"nın şu mısralarında görülmektedir:

“Muhbirler senin eşkâlini verdiler,

en son seninle görmüşler.

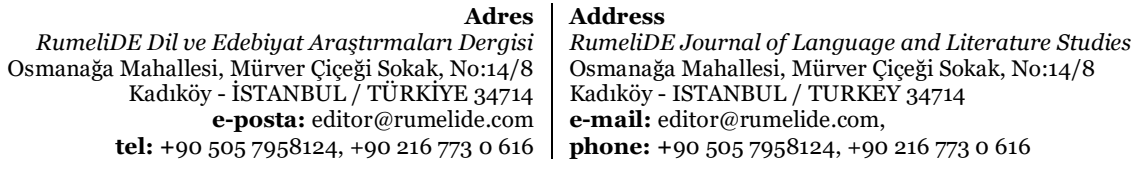


Aklımı ne yaptın Esmeralda?” (Coşkun, t.y.a., s. 7)

Burada kastedilen sevgilinin güzelliğinden ve sevenin aşkının yoğunluğundan dolayı aklın ötelenmesidir. Fakat “Esmeralda"nın şu mısraları kadın için aklın, erkek için ise gönlün öncelendiğini vermektedir:

"Sevdan yer edeli sinsice sinede,

Aklı senden

Kalbi benden yana

Aşkımızla böldüğümüz fertlerin.” (Coşkun, t.y.a, 7)

$\mathrm{Bu}$ mısralarda kadının ve erkeğin birlikteliğe bakış açıları verildiği gibi, çevrenin bireyleri bu yönde hareket etmelerine sebep olduğu da hissedilmektedir. Bu husus çokça tartışllan bir mesele olup, erkeğin bakış açısının mı yoksa kadının düşüncesinin mi doğru olduğu birçok kere çeşitli vesilelerle ele alınmıştır. Fakat bilindiği üzere belirgin bir anlaşma söz konusu olamamıştır. Bu farklılığın fitratın etkisinden dolayı olduğu da varsayılabilir. Aşk; beşerî ve ilahî olarak sınıflandırılmış ve Yunus Emre'nin

“Leyla Leyla derken Mevlayı buldum” (Hatipoğlu, 1993, 31)²

mısrasında verildiği üzere masiva aşkı, mavera aşkına ulaşmak için mutasavvıflar tarafından bir basamak olarak görülmüştür. Reşat Coşkun'un İstanbul'da kabri bulunan ve Kadirî tarikatı Halisiye şubesi mürşitlerinden olan Hafız Mustafa Uzgur'a intisabı (R. Coşkun ile kişisel iletişim: 23.07.2021)'ndan dolayı şairin "Hüzünzâde" adlı şiirinde geçen

"Nazın at koşturur,

Yalnız benim

Gönül ülkemde.” (Coşkun, 2001, 1)

mısralarında tasavvufta kıymetli olduğu bilinen gönül ıstılahı anımsandığı gibi "Ben yere ve göğe sığmadım ancak mümin kulumun kalbine sığdım” (el-Aclûnî, 1351, 195) şeklindeki hadis de akla gelmektedir. Ayrıca şiirin,

"İçimdeki yolculuğumun,

Taif etabındayım farz et.

Enel-Hak diyen Mansur'a

Gül atan Şibli ol veyahut” (Coşkun, 2001, 2)

mısralarında Hz. Peygamber’in Zeyd. B. Hârise ile beraber İslâm'a davet için gittiği ve halkı tarafından alay edilip taşlandığı Taif (Küçükaşçı, 2010, 444)'ten dolayı İslâm tarihi, Hallac-ı Mansur'dan dolayı ise tasavvuf ve ilahî aşk akla gelmektedir. Fakat bu dizelerin hemen sonrasında gelen

"Bil ki sen içinde surlar,

Surlar örerken bana;

Ben, şahiler dökerim

Sana ve surlarına.” (Coşkun, 2001, 2)

2 Bu şiir, Mustafa Tatcı'nın hazırlamış olduğu Dîvân-ı İlâhiyât adlı eserin “Âşsk Yûnus'un veya Başka Yûnuslar’ın Şiirleri” başlıklı bölümünde geçmektedir. (Yûnus Emre, 2014, 647-718.)

Adres | Address

RumeliDE Dil ve Edebiyat Araştırmaları Dergisi $\quad$ RumeliDE Journal of Language and Literature Studies

Osmanağa Mahallesi, Mürver Çiçeği Sokak, No:14/8 $\quad$ Osmanağa Mahallesi, Mürver Çiçeği Sokak, No:14/8

Kadıköy - ISTANBUL / TÜRKIYE 34714 Kadıköy - ISTANBUL / TURKEY 34714

e-posta: editor@rumelide.com e-mail: editor@rumelide.com,

tel: +90 505 7958124, +90 2167730616 phone: +90 505 7958124, +90 2167730616 
şeklindeki mısralarda yer alan aşkın beşerî, sevgilinin ise beşer olduğu görülmektedir. Bu mısralarda ilahi aşk aranmamalıdır. Çünkü ilahî aşk denildiği zaman şu hadis akla gelmektedir ki "Ebû Hureyre'den rivayet edildiğine göre Rasûlullah (S) şöyle buyurmuştur: Allah buyuruyor ki: Ben kulumun benim hakkımdaki zannı üzereyim. Bana dua ettiğinde onunla beraberim" (et-Tirmizî, 1975, Zühd, 51, Deavat, 131). Bu hadis ilahî aşkı ifade etmekte, sevgili olan Yaratan'ın naz etmediği, aksine kulunun O’na yaklaşması için âdeta bahane aradığını göstermektedir. Buradaki sevgi; beşerî aşk gibi değil, Yaratan’ın yarattığına yaklaşma isteğinin olduğu bir muhabbet hâlidir. Ayrıca naz, şiirimizde değişmeyen bir yapı olan kaçışın simgesi beşerî sevgiliye ait bir vasıftır ki bu şiirde de sevgili naz etmekte, sevene setler çekmekte, âşı ise İstanbul sevdasıyla şahiler döktüren Fatih misali bu engelleri yıkacak ve ona sahip olacağını söylemektedir. Coşkun'un "Arzu” şiirinde ise hem tasavvuf hem de dünyevî bir birliktelik verilmekte, burada "sevgili”, "aşk", "gönül” mefhumlarının ele alındığı görülmekte, bu hususların hem beşerî aşka hem de ilahî aşka ait kavramlar olduğu ancak beşerî aşk ile ilahî aşkın beraber olamayacağı anlatılmaktadır:

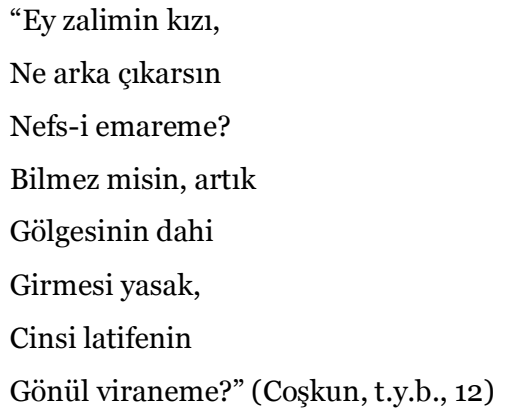

Burada uhra ile dünyanın beraberliğinin düşünülemeyeceği, aşk kavramı üzerinden ve sevgili ön plana çıkarılarak verildiği gibi, seven/şair en aşağıdaki nefs mertebesinde olduğunu vurgulayarak (bk. Yılmaz, 2017, 234-237) tevazu sergilemekte ve bu nefs mertebesindeki sâlik için beşerî sevgilinin uzak olmasına işaret edilmektedir. Ayrıca Coşkun'un bu nefs seviyesinde olduğunu söylemesi onun tasavvuf ehli olduğuna da ortaya çıkarmaktadır. Şair "Aşk" şiirinde ise bu nosyonun kendince tarifini yapmaktadır:

“Kısa ömrün

Uzun karıdır aşk

Kendini tüketmek pahasına

İçinde bir başkasını

Büyütmektir aşk..” (Coşkun, 2004, 6)

Şair burada halk arasında daha çok ticarette kullanılan "Kısa günün kârı" deyimini aşk kavramı için kullanmıştır. Ticarette de ürün tükenir ama meta yükselir. Kazanç çoğaldıkça bireyin refah seviyesi, buna bağlı olarak da mutluluğu artar. Şairin aşk tarifi de buna benzerdir. Aşk sevilen tarafından seveni tüketen, hüzne daldıran, zorlayan bir yaşantıdır. Nasıl ticarette ürünün tükenmesi sahibine huzursuzluk değil, mutluluk veriyorsa, aşkta da sevenin sevdiği için tükenmesi mutluluk olarak görülmelidir. Çünkü sevgili aşkından dolayı âşıktadır. Bu şiirdeki gibi "Senim Ben” şiirinin,

"Beni bana bırakmanı,

Hiç istemedim sen giderken...” (Coşkun, t.y.b., 29)

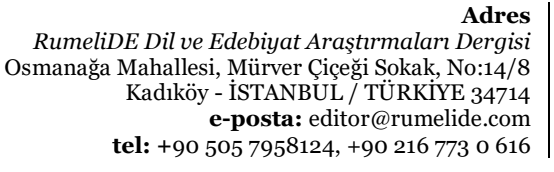

Adres Osmanağa Mahallesi, Mürver Çiçeği Sokak, No:14/8 e-posta: editor@rumelide.com tel: +90 $5057958124,+902167730616$
Address

RumeliDE Journal of Language and Literature Studies

Osmanağa Mahallesi, Mürver Çiçeği Sokak, No:14/8

Kadıköy - ISTANBUL / TURKEY 34714

e-mail: editor@rumelide.com,

phone: +90 5057958124 , +90 2167730616 
mısralarında da sevgiliyle beraber olmak istenmektedir. Ancak bu mısralar nefs kavramını ve "Ey Allah'ım! Senin rahmetini umuyorum, beni göz açıp kapayıncaya kadar (da olsa) nefsimle baş başa bırakma. Halimi tümüyle düzelt, Senden başka ilâh yoktur" (Ebû Dâvûd, 2009, Edeb, 110) şeklindeki hadisi hatırlatmaktadır. Burada nasıl kulun nefsi ile beraber olmaktan çekinmesi verilmişse şiirde ise âşı/kşair içindekinin kendi "ben”i yahut "nefsi” olmamasını bunun aksine sevgili olmasını istemektedir.

\subsection{Hüzün ve karamsarlık}

Hüzün ve karamsarlık modern Türk şairleri arasında çokça işlenmiş bir temadır. Bunun sebebi ise hayat ve hayatın getirdiği yaşantıların çoğunlukla hoş olmayan deneyimler olmasındandır. Hüzün ve buna bağlı olarak oluşan karamsarlık insan psikolojisinin çeşitli olumsuz deneyimleri sonucu oluşan, bazen patolojik boyutlara kadar varan bir ruh hâlidir. Bu ruhsal duruma sebebiyet veren saikler ise ayrilık, ölüm, sevgili, gurbettir... Bu sebeplerin yanında yer alabilecek yaşlllı̆̆ın hüzün sebebi oluşu ise “İhtiyarlık” şiirinde görülmektedir:

“Zaman sel gibi aktı,

Ve geçti,

İçimde ahlarımı,

Yüzümde çizgileri,

Derinleştirerek.

İhtiyarlık bu olsa gerek.” (Coşkun, t.y.b., 14)

Burada yer alan ilk mısra dikkat çekicidir. "Su gibi aktı" deyimi yerine “...sel gibi aktı" denmesi şairdeki ihtiyarlık ile oluşan hüznün derinliğini ve onda bıraktığı etkinin yoğunluğunu da göstermektedir. Bu mısralarda ihtiyarlığın verdiği hüzünlü ruh hâli "Dünya" şiirinde de işlenmektedir. Aynı duyguların birden çok şiir içinde ele alınması, şairin hüznünden ve yılların ondan götürdüklerinden dolayı oluşan karamsarlığın ürünü olduğu söylenebilir:

"Dünden kalma saçımdaki

Üç beş siyah da olmasa

İnanmayacağım,

Bir zamanlar

Benim de genç olduğuma.” (Coşkun, t.y.a., 36)

$\mathrm{Bu}$ mısralardaki ruh hâli; geçmişi, geçmişteki güzel günleri, kendisinin sanki hiç genç olmadığını düşünme, hâldeki ihtiyarlık psikolojisinin içinde kendisiyle barışık olmadan yaşama, şairdeki hüznün ve karamsar durumun yoğunluğunu göstermektedir. Coşkun'daki bu olumsuz yapının, geçmişle günün kıyasının verdiği karamsarlıktan kaynaklandığı söylenebilir. Ayrıca bu ruh hâli geçmişin bir daha gelmeyeceğinin bilinmesinden dolayıdır. Bunun sebebi ise bilinçaltında ölüm psikolojisinin bireye sirayet etmesi olarak ifade edilebilir.

Hüzün denildiği zaman,

"hüzün ki en çok yakışandır bize

belki de en çok anladığımız” (Yavuz, 2006, 65)

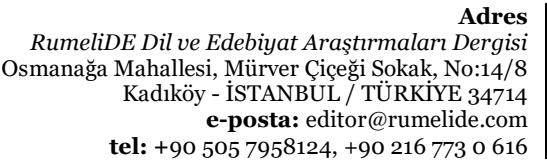

RumeliDE Dil ve Edebiyat Araştırmaları Dergisi Kadıköy - ISTANBUL / TÜRKIYYE tel: +90 505 7958124, +90 2167730616
Address

RumeliDE Journal of Language and Literature Studies

Osmanağa Mahallesi, Mürver Çiçeği Sokak, No:14/8

Kadıköy - ISTANBUL / TURKEY 34714

e-mail: editor@rumelide.com

phone: +90 5057958124, +90 2167730616 
mısralarından dolayı Hilmi Yavuz akla gelmektedir. Reşat Coşkun”un “Hüzün Şık Durur Üzerinde” şeklindeki şiirinin başlığı bu mısraları hatırlatmaktadır:

\author{
“Âsûde akşamların fevkindeki \\ Mahzenlerde acılar yıllanır. \\ Gayrı kalmaz kimseye intizârın \\ Döneceksin mahzun güneş gülünce \\ Târümar akşamlara deva için \\ Gam tükenende sabrî cemîlinde \\ Hüzün şık durur artık üzerinde.” (Coşkun, 2001, 6)
}

Bu mısralarda özellikle "akşam", "hüzün”, "mahzen”, "mahzun” ayrıca "intizâr”, "târümar" ve "gam” kelimeleri şiirdeki hüzün hâlini belirginleştiren sözcüklerdir. Bu sözcükler akşamın karanlığından, kasvetinden dolayı özellikle seçilmiş olup, "Döneceksin mahzun güneş gülünce" mısrası da yine bir zamanı, huzursuzluğun mevsimi kışı ya da karamsarlığın dönemi hazanı vermektedir. Şiirdeki "sabrî cemil” ise Arapça bir terkip olup güzel sabır anlamında kullanılmakta ve bizi "(Babaları) dedi ki: Hayır, nefisleriniz sizi (böyle) bir işe sürükledi. (Bana düşen) artık, güzel bir sabırdır. Umulur ki Allah onların hepsini bana getirir. Çünkü O çok iyi bilendir, hikmet sahibidir" (Karaman vd. 2015, 231) şeklinde meâli verilen Yûsuf suresi 83. ayete götürmektedir. Bu ayette yer alan "güzel bir sabır" terkibi Hz. Yakub'un oğlunun döneceğine umudunun olduğunun göstergesidir. Bu şiirde de "güzel bir sabırla" beklerken "gam tükenecek" yani sevgili gelecektir. Fakat o zaman âşık olmayacağı için mısrada vurgulandığı üzere sevgilinin "Hüzün şık durur artık üzerinde."

\title{
1.3. İnanç
}

Reşat Coşkun şiirinde inanç teması; din, tasavvuf, hadis ve ayetlerin şiirlerde yer almasıyla işlenmektedir. Bu temanın şair için önemli olduğu, şiirinde yoğun bir şekilde bu temayı kullanmasından anlaşılmaktadır. Bunun kullanımın yoğun olmasının sebebi ise şair için inanç nosyonunun kıymetli olması ve şairin bu anlayışı yaşam biçimi olarak görmesinden dolayıdır. Bu yargının doğruluğu, şair ile iletişim kurulduğunda sorulmuş ve şair tarafından da tasdik edilmiştir (R. Coşkun ile kişisel iletişim: 27.07.2021).

\subsubsection{Din}

Din, genel bir mefhumdur. Fakat bu çalışmada tasavvuf kavramından farklı olarak başlıklandırılacağından dolayı böyle bir ayrımın yapılması gereği duyulmuştur. Ancak bu durum tasavvufun dinden ayrı bir yapı olduğu anlamına da gelmemelidir. Din, birçok modern Türk şairi tarafından kullanılan bir temadır. Bunun sebebi ise insanoğlunun yaratılışından bu yana sığınacak, korunacak, kendini güvende hissedecek, ruhunu teskin edecek bir güç arayışında olmasındandır. İnanma, dua etme, ibadetleri yerine getirme hep bu dinginliği aramanın sonuçlarıdır. Şairin "Duacı" şiiri, adından dolayı bir beklentinin olduğunu işaret etmekte, okuyucuya şairin anne babasından, bir din adamından, çevresindeki kişilerden dua istediği ve ona dua edildiği düşüncesini akla getirmektedir. Ancak bu şiirdeki duacı nebatattandır; ağaçtır, fidandır. Dua bekleyen ise kabir ehlidir. Bu anlayış halk inancından gelmektedir. Burada kabrin üstüne dikilen ağaçların yahut fidanların sallandıkça mevtaya dua etmesi, günahlarının bağışlanmasına vesile olması inancı görülmektedir:

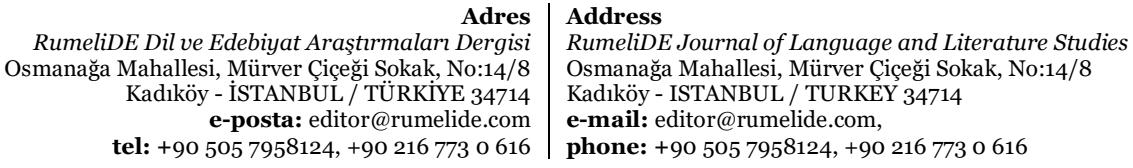

Adres
RumeliDE Dil ve Edebiyat Araştırmaları Dergisi a i, Mürver Çiçegi Sokak, No.14/8 el: +90 $5057958124,+902167730616$

phone: +90 505 7958124, +90 2167730616 
"Benim de bir
Duacım olsun istersen
Dikili bir ağacın olsun.
Her fidanın dalları
Senin için daima
Semaya el açar..
Duaya durur.
Mutluluğun için
Niyazda bulunur.
İyiliğine şahit olur" (Coşkun, t.y.a., 35)

Sadaka bilindiği gibi İslâm dininde var olan ve verilmesi tavsiye edilen bir dini gerekliliktir. Bu gerekliliğin yapılmasının sebebi hayattakilere de memattakilere de fayda ettiği inancıdır. Yaşayanların kaza ve belalardan korunmak için verdiği bilinen sadakanın, ölenler için nasıl bir fayda sağlayacağı şairin "Sadaka" şiirinde verilmektedir:

"Senden olanların toprak olanlarına,

Bir şeyler ihsan etmek istiyorsan,

Sadaka-yı cariye adına;

Ölmüşlerinin incittiklerinin

Yaşayanlarının, derman olmalısın

Gönül ızdırabına.” (Coşkun, t.y.b., 62)

Kazanın İslâm'da bazı ibadetlerin daha sonra yapılmasının ruhsatı olduğu bilinmektedir. Yani bu husus fıkı ilminin mevzularındandır. Bu din terimi Coşkun'un kitabına da adını verdiği "Sevdam Kaldı Bir" şiirinde dinî bir mantaliteyle değil, sadece benzetme olarak kullanılmaktadır. Din mefhumunun bu şekilde kullanımı da Reşat Coşkun şiirinde görülmektedir:

"Kendim için dünyevî, uhrevî,

Bütün beklentileri,

Kazâya bıraktım.” (Coşkun,2001, 47)

Bu mısralar; umutsuzluğun, bir diğer başlıkta da yer alan şairin şiirinin özelliklerinden olan karamsarlık hâlinin dinî terminoloji içinde şiirleşmesidir.

\subsubsection{Tasavvuf}

Reşat Coşkun şiirinde en belirgin, hatta en fazla şiir, tasavvuf teması üzerine yazılmıştır. Bunun sebebi şairin tasavvuf ehli olmasından kaynaklandığı söylenebilir. Şair; tasavvufu bilinçsiz bir şekilde değil, doğrularla, İslâm'ı kriter alarak yaşamak amacında olduğunu ve gerek şiirlerinde gerekse de öykülerinde bilinçsiz müntesiplere de çattığını ifade etmiştir (R. Coşkun ile kişisel iletişim: 27.07.2021). Şair, "Demirci Eren" şiirinde demirci metaforuyla tasavvufu ve dervişliğini anlatmaktadır. Coşkun; burada tasavvufta temel ıstılahlardan olan mürşit, nefs, aşk ve ham olma unsurları ile mutasavvıflar için kıymetli olan şeriat, tarikat, hakikat ve marifet kavramlarıyla ayrıca Yunus Emre'nin dervişliğine telmih olarak yapılan "eğrilik" benzetmesiyle tasavvufu ve dervişliğini yansıtmaktadır:

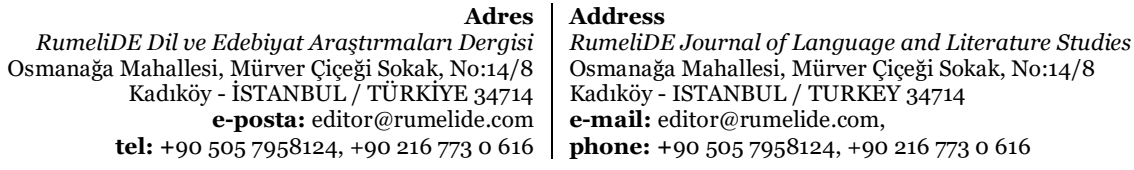




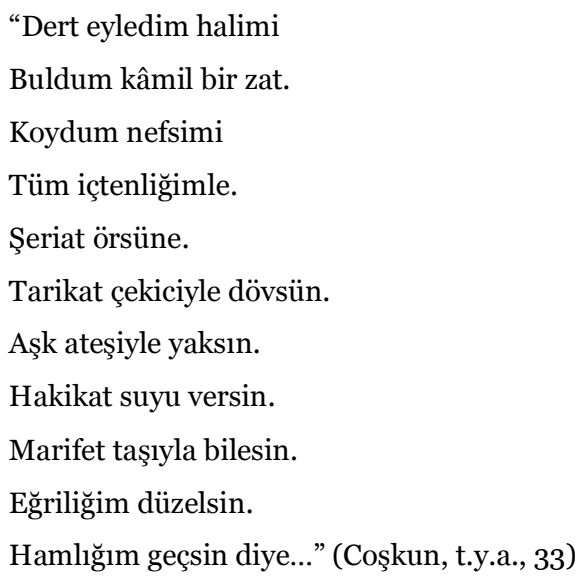

Son iki dize şairin tevazusu olarak da okunabildiği gibi bu şiirde geçen "kâmil zat"ın olup olmadığı, varsa kim olduğu sorusu üzerine Coşkun böyle bir mürşidinin bulunduğunu ve bu kişinin şu an vefat etmiş olan Hafız Mustafa Uzgur olduğunu bildirmiştir (R. Coşkun ile kişisel iletişim: 27.07.2021). Bu şiirde "eğrilik" telmihi ile yapılan tevazu, dervişlik adabı gereği övünmeyip kendini yerme hâli "Odun" şiirinde de işlenmiştir:

“Eyvah, yine bana eğri odunu,

Ĕ̆ri gönlü,

Dergâhtan içeri sokmak kaldı." (Coşkun, t.y.b., 39)

Burada şair/derviş dergâhı aslında eğriliklerin düzeltildiği, gönle inen teşvişlerin atıldı̆̆ı bir yer olarak gördüğü için buraya teslim olmak gerektiğini vurgulamaktadır. Tasavvufta en önemli istılahlardan biri nefs kavramıdır. Amaç, emmâre nefsten kâmile/sâfiye/râdıye nefse ulaşma gayretidir (Nefs mertebeleri için bk. Türer, 1995, 135-141). Şiirin devamında ejderha misali nefsinin olumsuzluklar ile büyümesinden ve hiddetinin artmasından teskin olmasına doğru evrilen seyr u sülûk hâlini işlemektedir:

"Günahlar işlerdim

Devam ettikçe,

Her günahın ardından,

Ruhumu, karşıma dikilmiş

Bir ejderha bulmaya.

Ne zaman ki başladı,

Ejderham uysallaşmaya,

İşte o zaman başladım

Korkmaya.” (Coşkun, t.y.b., 39)

Burada nefsin uysallaşmasıyla beraber korkmaya başlaması artık dervişin nefsinin karşı çıamamasından yani Allah'a tabi olmasından dolayı olduğu söylenebilir. Tasavvufun en temel terimlerinin mürşit ve mürit olduğunu söylemek belki yanlış olmayacaktır. Mürşidin/şeyhin görevinin müridin/dervişin seyr u sülûkunun nihayete ulaşması için ona rehberlik etmesi, dervişi Allah'a vasıl olma yolunda güneş misali aydınlatması; müridin görevi ise şeyhine hulus ile yani tam bir teslimiyetle, kalbi mutmain olarak ayçiçeği misali boyun bükmesidir. Bu hâl "Çiçekler" şiirinin şu mısralarında işlenmektedir:

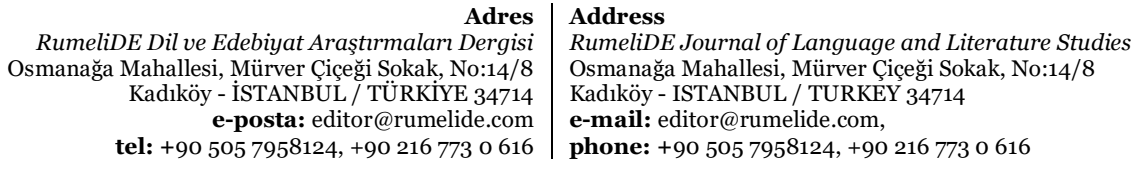


"Derviş olmuş ayçiçeği,

Şeyh edinmiş güneşi.” (Coşkun, 2001, 4)

$\mathrm{Bu}$ şiirde vurgulanmak istenen teslimiyet, tasavvuf erbabı için elzemdir. Çünkü kalpte teşvişlerin olması sülûka zarar verecektir. Ancak bu, dervişin mürşidine her durumda -İslâm'a uymayan davranışları olsa bile- bağlı olması anlamına gelmemelidir. Dervişin hassasiyeti ve ölçüsü dininin emir ve nehylerine göre hareket etmesidir. Bu çizgi dahilinde mürit mürşidine tam bir teslimiyetle bağlanması gerekir ki Allah'a vasıl olma yolunda nefs mertebesini ilerletebilsin. Coşkun'un "Teslimiyet” şiiri bu bağlllı̆̆ı; tasavvufta önemli oldukları bilinen "sükûnet”, "teslimiyet”, "benlik”, "hikmet”, "hakikat” ve "marifet” kavramlarıyla vermektedir:

“Tam bir sükûnetle
İsmail'den kalma
Teslimiyetle
Benliğimi koydum
Senin örsüne
Hikmet çekiciyle
Dövesin...
Hakikat ateşiyle
Marifet suyu
Veresin diye...” (Coşkun, 2004, 71)

Tasavvuf büyüklerine çeşitli şairler, şiirlerinde yer vermektedirler. Bu tasavvuf büyüklerinden daha çok Hallac-ı Mansur, Hz. Mevlânâ ve Yunus Emre'ye vurgu yapılmaktadır. Fakat İbnü’l Arabî, Bâyezid-i Bistâmî, Cüneyd-i Bağdadî, İbrahim Ethem gibi mutasavvıflara da yer yer değinilmektedir. Tarikat piri olarak ise Abdülkâdir Geylânîye de yer verilmektedir. Reşat Coşkun şiirinde de bu tasavvuf büyügüne işaret edilmektedir. Bunun en önemli nedeni ise şairin Kadirî müntesibi olmasıdır. Esmeralda şiirinin

“Belasız yakınlığın arzularken,” (Coşkun, t.y.a., 9)

misrainda,

“Allah’ım, bizi bela ile deneme. Bize belasız yakınlık ver. Bize yakınlık ve lütuf ihsan eyle!.. Ateş âfetini göstermeden yakınlığını nasip eyle... Şayet âfet mukadderse, bizi semender (ateş içinde yaşayan bir kuş) gibi kıl. O ateşle beyazlanır, yanmaz; bilâkis rahat eder. Bela hâlimizi, İbrahim’in (a.s.) ateşine çevir. Ona yaptığın gibi bize verdiğin ateş de olsa içinde yeşillikler olsun. Bizi bütün varlıktan müstağni eyle. İbrahim Peygamber’i de öyle eylemiştin. Bize ülfetini ver ve bizi onu esirgediğin gibi esirge... Âmin!..." (Abdulkadir Geylanî, 2000, 77)

şeklindeki Abdülkâdir-i Geylânî’nin duasına iktibas yapılarak tasavvuf işlenmektedir. “Aşk ile Akıl Duruşmaları" şiirinin bir bölümünde

"Hayat aldı, ölüm saçtı.

İnsanları ayırdı da ayırdı.

Ancak kalp sahibi birisi.

Ne olursan ol yine gel dedi.” (Coşkun, t.y.a., 19, 20)

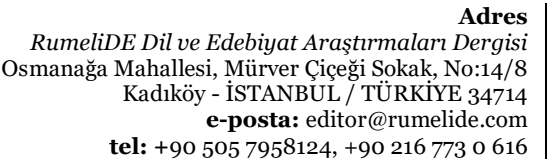

Adres RumeliDE Dil ve Edebiyat Araşțrmaları Dergisi tel: +90 $5057958124,+902167730616$
Address

RumeliDE Journal of Language and Literature Studies

Osmanağa Mahallesi, Mürver Çiçeği Sokak, No:14/8

Kadıköy - ISTANBUL / TURKEY 34714

e-mail: editor@rumelide.com,

phone: +90 505 7958124, +90 2167730616 
mısraları dikkat çekmektedir. Bu mısralar bizi Yakup Şafak’ın "Mevlânầya Atfedilen "Yine Gel..." Rubâîsine Dair" adlı makalesine götürmektedir. Bu makalesinde Şafak; Mevlânâ'ya atfedilen bu rubainin Ebû Said-i Ebu'l-Hayr ve bazı sufi şairlere de atfedildiğini, bu şiirin kime ait olduğunun net bir şekilde bilinmediğini ifade etmektedir. (Şafak, 2009, 75)

\subsubsection{Ayet ve hadislerin kullanımı}

Reşat Coşkun şiirinde İslâm inancı önemli bir yer taşımakta, çeşitli ayet ve hadislere telmih yapılarak inanç kavramı şiirlerde işlenmekte yahut bu nosyona değinilmektedir. Şairin “Halil’im” şiirinin

"Hep İbrahim gibi çıtın.

İçimde senden gayri neyim varsa

Yakıp kül eden o yangından.” (Coşkun, t.y.a., 49)

mısralarında ayet-i kerimeye telmih yapılmıştır. Bu ayet meali "Ey ateş! İbrahim için serinlik ve esenlik ol dedik" (Karaman vd., 2015, 315) şeklindeki Enbiya suresi 69. ayettir. Şiirin başlı̆̆ını ise "Hz. İbrâhim edebî eserlerde babasına nisbetle İbrâhîm-i Âzer, İbn Âzer, Halîl, Halîlullah, Halîlürrahmân, Halîl-i Akdes adlarıyla da anılmıştır” (Uzun, 2000, 273) bilgisi açıklar niteliktedir. Bu ayete bir başka telmih ise "Sen.." şiirinin

"Sen, Nemrudu odlar sonrası

Gönlümde açan gülistan.” (Coşkun, t.y.a., 114)

şeklindeki mısralarıdır. Hz. Yusuf kıssası gerek nesir gerekse de şiir olsun birçok edebî metinde işlenmiştir. Bu kıssada yer alan kuyu, rüya, saray gibi hususlar çokça işlendiği gibi bu unsurların yanında Züleyha ve zindan da ele alınmıştır. Bu iki unsur, Coşkun'un "Vuslatı Olmayan Sevdam” şiirinde hatırlatılmaktadır:

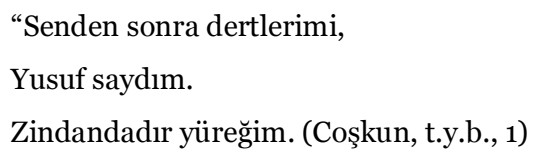

Bu mısralar Yûsuf suresi 32. ayete bizi götürmektedir. Ayet şu şekildedir: "Kadın dedi ki: İşte hakkında beni kınadığınız şahıs budur. Ben onun nefsinden murat almak istedim. Fakat o, (bundan) şiddetle sakındı. And olsun, eğer o kendisine emredeceğimi yapmazsa mutlaka zindana atılacak ve elbette sürünenlerden olacaktır!” (Karman vd., 2015, 225) Coşkun'un “Akabede” şiiri ise okuyucuyu Mekke'de Mescid-i Harâm'a 3 km kadar uzaklıkta ve Mina hudutlarında olan Akabe Biatları'nın yapıldığı yere ve olaya (Önkal, 1989, 211) götürmektedir. Ayrıca şair bu şiirin

“Elele verdik.” (Coşkun, 2001, 64)

mısrasının ise Fetih suresinin 10. ayetinden mülhem olduğunu ifade etmiştir (R. Coşkun ile kişisel iletişim: 30.07.2021). Bu ayetin meali şu şekildedir: "Muhakkak ki sana biat edenler ancak Allah'a biat etmektedirler. Allah'ın eli onların ellerinin üzerindedir. Kim ahdini bozarsa ancak kendi aleyhine bozmuş olur. Kim de Allah ile olan ahdine vefa gösterirse Allah ona büyük bir mükâfat verecektir" (Karaman vd., 2015, 504). Şiirin devamında yer alan

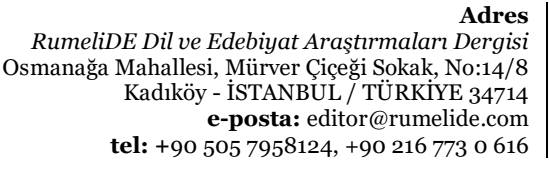

RumeliDE Dil ve Edebiyat Araştırmaları Dergisi Kadlköy - ISTTANBUL / TÜRKIYY tel: +90 505 7958124, +902167730616
Address

RumeliDE Journal of Language and Literature Studies

Osmanağa Mahallesi, Mürver Çiçeği Sokak, No:14/8

Kadıköy - ISTANBUL / TURKEY 34714

e-mail: editor@rumelide.com,

phone: +90 5057958124 , +90 2167730616 
“Mevlâ ikinin üçüydü.” (Coşkun, 2001, 64)

misrası ise

“Göklerde ve yerde olanları Allah'ın bildiğini görmüyor musun? Üç kişinin gizli konuştuğu yerde dördüncüsü mutlaka O'dur. Beş kişinin gizli konuştuğu yerde altıncısı mutlaka O'dur. Bunlardan az veya çok olsunlar ve nerede bulunurlarsa bulunsunlar mutlaka $\mathrm{O}$, onlarla beraberdir. Sonra klyamet günü onlara yaptıklarını haber verecektir. Doğrusu Allah, her şeyi bilendir” (Karaman vd., 2015, 541)

şeklindeki Mücâdele suresinin 7. ayetine telmihtir.

Şairin bu şïrlerinde görülen bazı ayet telmihlerinin yanında hadislere de gönderme vardır. Coşkun, “Aşk ile Akıl Duruşmaları" şiirinin

"Bil ki aklı olmayanın yoktur dini.

Muti ise sen de bilirsin bunu. "(Coşkun, t.y.a., 20)

mısralarında yer alan "Muti”nin "Mûtû kable en-temûtû"dan ilham alınarak yazıldığını söylemiştir (R. Coşkun ile kişisel iletişim: 30.07.2021). Şaire ilham olan bu ifade "Ölmeden evvel ölünüz" (el-Aclûnî, 1351, 29) şeklindeki hadis-i şeriftir. Coşkun’un “Hüzün Laleleri” adlı şiirinin

"Yere göğe sı̆̆arım.

Kendime sığamam.” (Coşkun, t.y.a., 57)

mısraları da yine okuyucuyu başka bir hadise, "Ben yere ve göğe sığmadım ancak mümin kulumun kalbine sı̆̆dım" (el-Aclûnî, 1351, 195) hadisine götürmektedir. Ayrıca bu hadis zımnen "Papatya Hüznü” şiirinin

"En yüce makam olan

Gönlümde oluşundan

Cesaret bularak.” (Coşkun, t.y.a., 103)

mısralarında işlenmiştir. "Dostlar” şiirinde ise bir başka hadise iktibas yapılmıştır:

"Bunun için Sevgili,

'Benim dostlarım

Yıldızlar gibidirler'

Buyurdular.” (Coşkun, 2001, 17)

Bu mısralarda dikkat edilirse "Sevgili" sözcüğü Hz. Peygamberi karşıladı̆̆ı için büyük yazılmış ve son mısra ise söylediler yerine "buyurdular" şeklinde saygı ifadesi olarak şiirde yer almıştır. Şairin dinî edep dahilinde yazdığı bu mısralar "Ashabım yıldızlar gibidir, hangisine uyarsanız doğru yolu bulursunuz" (Zehebî, t.y., 141, 142) hadisine okuyucuyu götürmektedir. "Bilinme Günahı"nın şu mısraları ise "Bilinmeyen gizli bir hazine idim, bilinmek istedim, bilineyim diye halkı (kâinat) yarattım" (el-Aclûnî, 1997, 132) hadisini hatırlatmaktadır:

"Bizden bilmemiz istendi.

Biz ise bilinmek istedik” (Coşkun, t.y.a, 29)

"Damla" şiirinde de şairin hadislerden yararlandığını görülmektedir. Bu şiirin

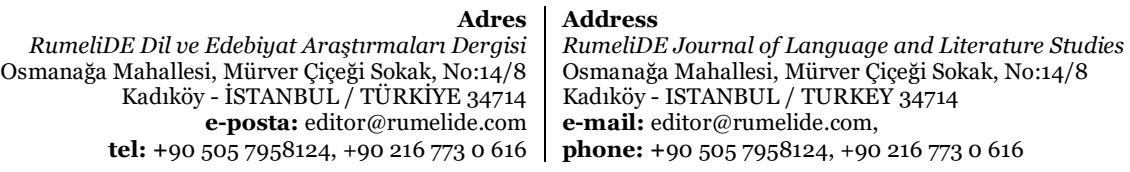


“Tövbesinin akabinde.

Affettirmek ümidiyle

Kendisini verdi iyiliğe...” (Coşkun, t.y.a., 31)

şeklindeki mısraları "Bir kötülük işlediğinde arkasından bir iyilik yap ki kötülüğü yok etsin” (et-Tirmizî, 1975, Birr, 55) şeklindeki hadis-i şeriften mülhemdir.

\subsection{Yerellik}

Öykü yazarı da olan Reşat Coşkun şiirinde yerellik kavramı hikâyelerine oranla daha azdır fakat bazı şiirlerinde bu hassasiyet görülmektedir. Hassasiyet denmesinin sebebi ise şair/yazarın memleketi Erzurum'daki yaşanmışlıklarına dair bir vefa borcu olarak görmesindendir. (R. Coşkun ile kişisel iletişim: 07.08.2021) Reşat Coşkun'un şiirine yerelliğin ağız kullanımı olarak girdiği görülmektedir. Bu şiirlerden biri "Yarının Duyguları"dır. Bu şiirde kullanılan ağız, Erzurum yöresinde öpmek anlamında kullanılan "baç almak" ifadesidir:

"Zorun da zorudur

Otururken duvarlar arasinda,

Bahçelerde koşmak,

Çiçeklerin kokusunu duymak.

Çocukların yanaklarından

Baç almak.” (Coşkun, 2001, 12)

Yerellik, Coşkun'un şiirinde bazen de Erzurum'un coğrafyasıyla ve de yörede "Es deli rüzgâr es dadaşı/yiğidin bağrına” gibi sık kullanılan bazı ifadelerin şiire alınmasıyla görülmektedir. Bu ifadeler, Erzurum ile özdeşleşmiş bir çiçek olan "Kardelen"in başlık olarak kullanıldığı şiirde şu şekilde verilmektedir:

"Palandöken dağında,

Soğuğa bağrını açıp,

Es yiğidin bağrına

Derken, Kardelen...” (Coşkun, 2001, 27)

Coşkun'un şiirinde yerellik kullanımı çocuk oyunlarıyla da işlenmektedir. Bu oyunlardan olan ve birçok şehirde olduğu gibi Erzurum'da da çocuklar arasında sıkça oynanan topaç oyununda iyi olan topaca "Buz gabaram" yahut "Buz gabarama" denilmektedir. Bu kullanım yöreye ait dilsel özelliklerden olan "k"nin "g" hâline hatta boğazdan biraz da baskılı olarak çıkan "g" harfine dönüşmesine bir örnek olabilmektedir. Bu olayın ve yerelliğin görüldüğü şiir ise “Çatlak Ellerimdeki Misket”tir:

“Topacimin ucunda

Kapılardan aşırdı ̌̆ım

Buz gabaram derdi, de.” (Coşkun, 2001, 38)

Bu şiirde yerellik bağlamında dikkat çeken başka bir şey daha var ki misket ifadesinin ağız yapılmadan kullanımıdır. Çünkü Erzurum'da misket ismi kullanılmaz; bunun yerine "bilye" hatta sesi biraz daha yuvarlaklaştırarak "bilya" veya "bılya" şeklinde kullanım yaygındır. Ancak şiirde, hem başlıkta hem de

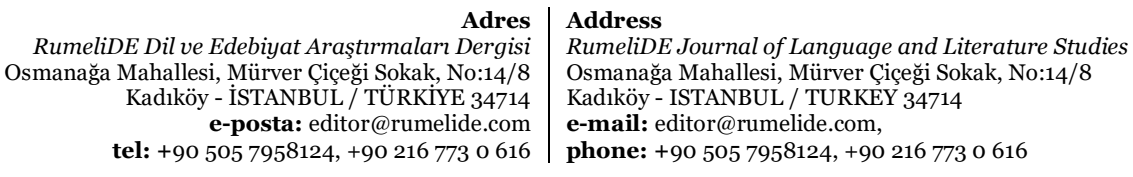


"O mu, diye başlayan

Anlatımın;

Ne bileyim, bana

Çatlak ellerimde misketimsin.” (Coşkun, 2001, 38)

şeklindeki dizelerde görüldüğü üzere ağız kullanımı yapılmamıştır. Yerellik kullanımı bir sitayiş olan "Erzurum" şiirinde şehrin tarihiyle beraber görülmektedir:

“Şehir içinde Erzurum'dum.

Başım bulutlara değdiği için

Mağrurdum...

Roma, Bizans, Selçuklu, Osmanlıyı

Şimdi de son Türk Devletini koruyorum

Dar vakitlerin şehriydim.

Geniş zamanlarda unutuldum...” (Coşkun, 2004, 26)

Son dize ile şairin şiirinde kullandığı temalardan biri olan eleştiri de yapılmaktadır. Şair, zor zamanlarda hatırlanan ama rahat dönemlerde anılmayan, unutulan şehir olarak yönetimlere eleştiri de bulunmaktadır.

Erzurum'da herhangi bir kadının başka bir kadına veya erkeğin başka bir erkeğe ya da çocukların büyüklerine seslenişlerine karşllık "efendim", "buyurun", "ne istiyorsun", "ne diyorsun" gibi kullanımların yerine daha çok "can" bazen de kelime "caan" şeklinde uzatılarak kullanılır. Şair bu kullanımı, ses uyumunu da gözeterek "Esmeralda”da şu şekilde vermektedir:

"Ellerimde asıldığım

Çan, can can diye inledi.” (Coşkun, t.y.a., 7)

Geçmişte daha belirgin olsa da şu anda da Erzurum ağzında kullanımı devam eden bir sözcük vardır ki bu, evlat ismi yerine kullanılan bala ifadesidir. Bu, şairin “Ana ve Dua” şiirinde görülmektedir:

"Bir akşam ana balasını yanına aldı.

Yavrum dün sütten kesmiştim.

Şimdi ninniden keseceğim seni.

Kendi dualarınla uyuman lazım.” (Coşkun, t.y.a., 11)

Yerellik, Coşkun'un şiirinde Erzurum'un bazı coğrafî̀ merkezlerinin verilmesiyle de görülmektedir. Yakutiye, Erzurum'da merkez ilçe konumunda olan ve şehrin en kalabalık olduğu beldelerinden birisidir. Bu coğrafî konum "Fani” şiirinde ele alınmaktadır:

Karşısına geçip soluklandığım Yakutiye

Gölgeme yaslanarak yürüdüğüm yollar

Cevherimde sen varsin, yolcum diyen

Kendini bilmeyen neyi bilir ki.” (Coşkun, t.y.a, 42)

Yerellik kullanımı ve Yakutiye bir başka şiirde ise Arif Nihat Asya'nın Erzurum'u ziyaretinde şehrin entelektüellerinin oturduğu ve Unesco ödüllü bir işletmenin sahibi olan Nail Orhon’a

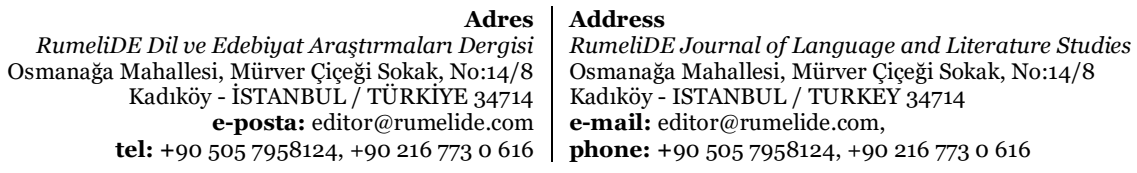


“-Nail sen neden vatanseversin, sebebini biliyor musun?

sorusu üzerine, Nail Orhon'un

-Bizi böyle yetiştirdiler.

şeklinde cevap vermesi ile Arif Nihat Asya

-Hayır! Sen bu Yakutiye’ye baktıkça aidiyetini hatırlıyorsun.”

demektedir (Bu hatırayı yaşayan M. Emin Alper ile kişisel iletişim: 07.08.2021) ve yerellik Yakutiye ile görülmektedir. Bu anının şaire yansıyan kısmı ise “Göç” şiiridir:

"Altı üstü,

Altı veya yedi saatlik

Dünya uykusunun

İlk saatlerinde

Kâbuslarla boğuşurken

Saniyelere sığan,

Emanet ömrümün

Gördügü,

En güzel rüyası idin sen...” (Coşkun, t.y.a., 43)

Reşat Coşkun özellikle burada verilen şiirin bu kısmının son dizesinin anlatılan hatıradan mülhem olduğunu ifade etmiştir. (R. Coşkun ile kişisel iletişim: 07.08.2021)

\subsection{Sosyal eleştiri}

Reşat Coşkun'un hem yazarlığının hem de şairliğinin ortak özelliklerinden biri de eleştirel bir tavrı öykülerine ve şiirlerine yansıtmasıdır. Ancak bu eleştiri, öykülerinde daha belirgindir. Fakat şiirlerinde de ayrı bir başlık açllacak kadar işlenmiştir. Gerek Türkiye'nin birçok şehrinde olsun gerekse Erzurum'da olsun önceki yaşantılar biraz da ekonomik şartlardan dolayı küçük evlerde geniş ailelerin yaşaması şeklindedir. Bu yaşam alanı mekân açısından dar olsa da kültürel anlamda bir birikimi beraberinde getirmektedir. Ancak yaşam kalitesinin artmasıyla beraber insanların birbirinden belirgin bir şekilde etkilenmesinden dolayı evlerin metrekaresi büyümesine rağmen birçok oda içinde sadece iki kişinin yaşadığı evlere doğru bir dönüşümün olduğu müşahede edilmektedir. Şair, "Evlerimiz"de bunun eleştirisini yapmaktadır:

"Evlerimiz büyüdükçe,

Yüreğimiz küçüldü.

Olmasa da büyüyen evlerimizin

Gelenleri,

Çoktur küçülen gönlümüzün,

Gidenleri.” (Coşkun, t.y.b., 38)

Günümüzde bir değişim süreci içerisinde olan tesettürün nasıl olduğu ya da olması gerektiği tartışılmaktadır. Reşat Coşkun da halkın sıkça yaptığı benzetmeleri kullanarak bir örtünme eleştirisi

Adres | Address

RumeliDE Dil ve Edebiyat Araştırmaları Dergisi Osmanağa Mahallesi, Mürver Çiçeği Sokak, No:14/8 Kadıköy - İSTANBUL / TÜRKIYE 34714 e-posta: editor@rumelide.com

RumeliDE Journal of Language and Literature Studies Osmanağa Mahallesi, Mürver Çiçeği Sokak, No:14/8

Kadıköy - ISTANBUL / TURKEY 34714 tel: +90 505 7958124, +90 2167730616

e-mail: editor@rumelide.com

phone: +90 505 7958124, +90 2167730616 
yapmaktadır. Şairin halkın kullanımlarını bazı şiirlerinde tercih etmesinin sebebi ise aydının halkın arasında olması gerektiği inancıdır (R. Coşkun ile kişisel iletişim: 08.08.2021). Bu fikriyatını şair, "Liman" şiirinde sosyal eleştiri olarak şöyle vermektedir:

“Aydınlar gördüm, gözlerini gözlerimden

kaçıran.

Yüzündeki ifadeyi

Görmemek için, halkına

Tepeden bakan.” (Coşkun, 2001, 35)

Şairin örtü eleştirisi ise “Çelişki”" şiirindedir:

"Kara saçın,

Billur bacaklarından güzel ki;

Örtmüşsün başın,

Açmışsın bacağın.

Bunca zaman yaşadım,

Hiç düşünmedim.

Bir binanın

Altının kilise,

Üstünün cami olacağın.

Söyle, ben de bileyim

Sana gelen ne yapmalı?” (Coşkun, t.y.b., 48)

Bu şiirde bir başka dikkat çeken husus vardır ki şairin "başını" yerine "başın", "bacağını" yerine "bacağın" ve "olacağını" yerine "olacağın" ifadesini kullanmasıdır. Bunun sebebi ise halk ifadelerine değer veren şairin yine ağız kullanımından kaynaklanmaktadır. Zamanın süreğenliğiyle beraber mimariden çocuk oyunlarına, giyim kuşamdan yapılan latifelere varana değin bir değişimin içindeki insanın görüntüleri "Yeni Zaman” şiirinde sosyal bir eleştiri yapılarak görülmektedir. Şairin asıl sorun ettiği ise samimiyetin yok olmasıdır yahut azalmasıdır:

"Makineler

Öğütüyor emeği

Sokaklardan

Kesildi çocuk sesleri.

$\cdots$

Merhamet kendini

Yalnız hissetmedi

Zaman içinde hiç bu kadar.

...

Tarih siliniyor

Coğrafyalar kayiyor.

Camlardan sarkan kadınlar

Seyyar satıcılara bağırmıyor.” (Coşkun, 2004, 79)

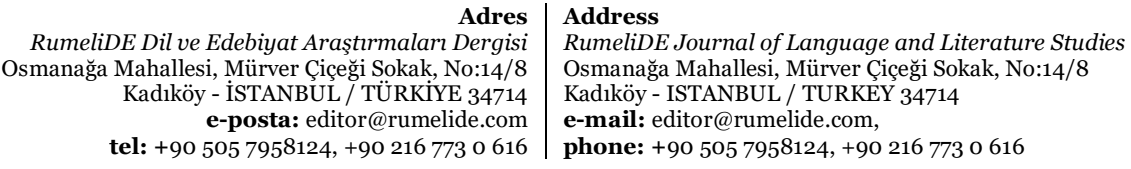


Aslında bu mısralarda şairin kapitalist mantaliteye eleştirisi, emeğe olan saygısı da görülmektedir. Mimarinin değişimine eleştiri bir başka şiirde "Kediler"de de vurgulanmaktadır. Burada kedilerin geçmesinin sebebini ise şair, eskiden evlerde kedilerin beslendiğinden ve o günlere olan özleminden dolayı olduğunu ifade etmiş̧ir (R. Coşkun ile kişisel iletişim: 08.08.2021):

"Eski evler

Katlara yenik düşeli,

Sokaklar kucakladı kedileri.” (Coşkun, 2001, 19)

Şair tasavvuf erbabı olmasına rağmen hem öykülerinde hem şïrlerinde yer yer yanlış bilinen ve uygulanan tasavvuf mantığına da karşıdır ve eleştirisini yapmaktadır. Tasavvufta paranın değersiz olarak görüldüğü bilinmektedir. Şairin "Mevlânâ" şiirinde hayatın algılanışının farklılaştığını, bu farklılaşmanın içine bazı tasavvuf ehlinin de girdiğini ve özellikle son zamanlarda semanın düğünlerde, şenliklerde vs. organizasyonlarda para ile yapılmasının da zımnen eleştirisini yaptığı görülmekte ve bunun müsebbibinin Hz. Pir değil, sonrasında gelenler olduğu vurgulanmaktadır:

“Ah Mevlânâ!

Seni anlamak,

Ne getirir ne götürür,

Paran kadar adam olduğun

Hayatın bu deminde,” (Coşkun, 2001, 22)

Coşkun'un, “Sevdam Kaldı Bir” şiirinde artık umutları kalmayan bir insanın ülkesinin insanlarına yaptığı eleştirisi daha ağır bir şekilde verilmektedir. Şairin bu kadar yoğun bir eleştiri yapması, umudunun artık olmamasından ve selvilerle işaret ettiği ölümü arayışından anlaşılmaktadır:

“Önce ümidimi kaybettim,

Ülkemin karayazılı coğrafyasında.

Yıkıldım geldiğim kanaatin sonunda.

Bu ülke adam olmaz.

Benim yırtınmam, boşuna.

Bir sevdam kaldı, bir de ben.

Yapayalnız, bozkırın ortasında

İki selvi derdiyle...

Sonra ölümün sevgililiğini

Kulağıma fısıldadı sevdam.” (Coşkun, 2001, 48)

\section{Sonuç}

Reşat Coşkun şiirinde yer alan bazı temalar dikkat çekmektedir. Bunlar; aşk ve sevgili, hüzün ve karamsarlık, inanç ve bu kavram içinde ayrı başlıklarda ele alınan din, tasavvuf, ayet ve hadislerin kullanımı ile yerellik ve sosyal eleştiri şeklinde olup, örneklem olarak seçilen şiirler tahlil yapılarak bu hususları şairin nasıl ele aldığı saptanmaya çalışılmıştır. Bu temalardan aşk ve sevgilinin sadece beşerî olarak değil, şairin tasavvuf erbabı olmasından dolayı ilahî aşk şeklinde de yansıdığı görülmektedir. Reşat Coşkun şiirine genel olarak bakıldığı zaman şairdeki üzüntü duygusu belirgin bir şekilde hissedilmekte ve bu duygu yoğunluğu hüzün ve karamsarlık olarak şairin şiirinde yer almaktadır. İnanç

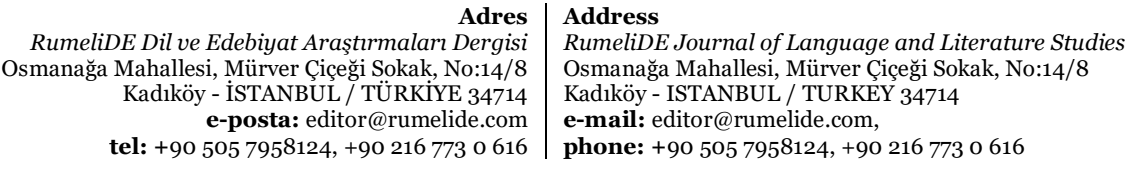


unsurunun ise Coşkun'un şiirleri arasında en sarih tema olduğu ifade edilebilir. Bu bağlamda ele alındığında tasavvufun belirginliği de dikkat çekmektedir. Bilindiği üzere Nakşibendîye Celvetiye, Halvetiye Çiştiye, Mevlevîye, Rufaîye, Kalenderîye, Halvetîye, Şazelîye gibi tarikatlar olduğu gibi Abdulkadir Geylani'nin pir olarak görüldüğü Kadirîlik tarikatı ve bu tarikatın birçok kolu bulunmaktadır. Coşkun'un şiirlerindeki tasavvufun belirginliğinin sebebi ise şairin bu tasavvuf yolunun Halisiye şubesine intisaplı olmasından dolayı olduğu söylenebilir. Ancak şair sadece müntesibi olduğu tasavvuf kurumunu değil, birçok şairin şiirlerinde de yer verdiği ve Mevlevîlerin piri olan Mevlânâ Celâleddin-i Rûmî̀yi de şiirinde ele almıştır. Bu hususun bir nedeni olarak Mevlânâ’nın özellikle Mesnevî adlı eserinin etkisi olduğu ifade edilebilir. Ayrıca bu hususun Coşkun'un erbabı olduğu Kadirîliğin yanında diğer tarikatlara da muhabbetle yaklaşımının görüntüsü olduğu da söylenebilir. Zaten şairin tasavvuf teması içinde yazdığı şiirlerinde muhabbetî bir yaklaşımın olduğu sezinlenmektedir. Bu husustan başka ele alınacak tematik bir diğer unsur ise şairin yerelliği şiirine katmasıdır. Şair, Erzurum'da doğmuş, bu şehirde eğitim almış ve bu şehirde yaşamıştır. Bu husus ise şiirine ağızlarla, şehrin bazı beldeleriyle ve Erzurum'a ait bazı söylemlerle yerellik olarak girmiştir. Şairin kendi açısından yanlış olarak gördüğü meselelerde eleştirel yapısı şiirinde sosyal eleştiri şeklinde temalaşmıştır. Bu temalar örnek alınan şiirlerin tahlil edilmesiyle açımlanmaya gayret edilmiştir. Şairle yapılan iletişim sonucu şiiri ile ilgili olarak verdiği hususlar da çalışmada yer verilerek Reşat Coşkun şiirinin daha belirgin bir şekilde okuyucuya yansıması hedeflenmiştir.

\section{Kaynakça}

Abdulkadir Geylanî. (200o). İlâhî Armağan (Fethu'r-Rabbani). (A. Akçiçek Çev.). İstanbul: Bedir.

Ebû Dâvûd, Süleyman b. el-Eşas es-Sicistânî. (2009). Sünen-i Ebî Dâvûd. yy.: Dârü’r-Risâleti'lArabiyye.

Ebû Îsâ Muhammed b. Îsâ et-Tirmizî. (1975). es-Sünen. Misır: Mektebetü ve Matbaatü Mustafa el-Bâyî el-Halebî.

el-Aclûnî, İsmail b. Muhammed. (1351). Kesfu'l-Hafâ ve Müzîlü'l-İlbâs ammeştehara mine'l-Ehâdîs alâ Elsineti’n-Nâs-II. Beyrut: Dâru İhyâi't-Türâsi'l-Arabî.

el- Aclûnî, İsmâil b. Muhamed b. Abdi'l-Hâdî el-Cerrâhî. (1997). Keşfu'l-Hafâ ve Müzîlü'l-İlbâs-II. Thk. Muhammed Abdu'l-Azîz el-Hâlidî. Beyrut : Dâru'l-Kitâbi'l-İlmiyye-

Coşkun, R. (2001). Sevdam Kaldı Bir. Erzurum: Kültür Eğitim Vakfı.

Coşkun, R. (2004). Sokak Lambası. İstanbul: Aktif.

Coşkun, R. (t.y.a.). Küheylan-“Hüdhüdü Beklerken”. İstanbul: Aktif.

Coşkun, R. (t.y.b.). Berceste-Vuslatı Olmayan Sevda. Erzurum: Kültür Eğitim Vakfı.

Hatipoğlu, A. (1993). Besteleriyle Yunus Emre İlâhîleri. Ankara: Türkiye Diyanet Vakfı.

Karaman, Hayrettin vd. (2015). Kur'ân-ı Kerîm Açılamah Meâli (3. bs.). Ankara: Türkiye Diyanet Vakfi.

Küçükaşçı, M.S. (2010). “Tâif”. TDV İslâm Ansiklopedisi içinde (Cilt 39, 443-447 s.s.). İstanbul: Türkiye Diyanet Vakfi.

Önkal, A. (1989). “ Akabe Biatları” TDV İslâm Ansiklopedisi içinde (Cilt 2, 211 s.s.). İstanbul: Türkiye Diyanet Vakfi.

Şafak, Y. (2009). Mevlânầya Atfedilen "Yine Gel..." Rubâîsine Dair. Tasavvuf İlmî ve Akademik

Araştırma Dergisi, 24 (2), 75-8o. Erişim adresi: http://yakupsafak.com/yazilar/46.pdf. Erişim tarihi: 28.07.2021.

Türer, O. (1995). Ana Hatlaryyla Tasavvuf Tarihi. İstanbul: Seha Neşriyat.

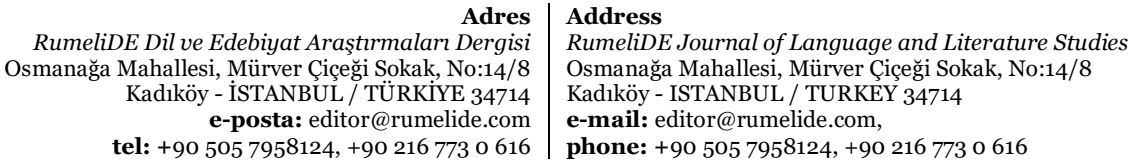


678 / RumeliDE Journal of Language and Literature Studies 2021.24 (September)

Thematic analysis of the poems by Reşat Coşkun / A. Karakuş (pp. 661-678)

Uzun, M.İ. (2000). “Türk Edebiyatı". TDV İslâm Ansiklopedisi içinde (Cilt 21, 272-273 s.s.). İstanbul: Türkiye Diyanet Vakfı.

Yavuz, H. (2006). Büyü'sün, Yaz!-Toplu Şïrler 1969-2005. İstanbul: YKY.

Yılmaz, H. K. (2017). Ana Hatlarıyla Tasavvuf ve Tarîkatlar (24. bs.). İstanbul: Ensar Neşriyat.

Yûnus Emre. (2014). Dîvân-ı İlâhiyât (3. bs.). Mustafa Tatcı (Haz.). İstanbul: H.

Zehebî. (t.y.). Mîzanu'lítidâl fí Nakdi’r-Ricâl, I-IV, Thk. Ali el-Becâvî, Beyrut: Dâru'l-Ma'rife-II.

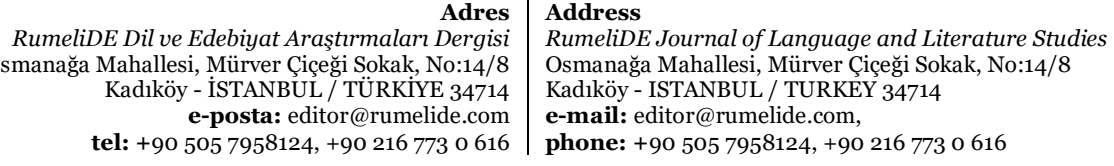

